\title{
Integrated Crop Management And Farmers' Group Dynamics In Arjasa Village
}

\author{
Lenny Widjayanthi \\ Agricultural Extension Department Agricultural Faculty Jember University Jl. Kalimantan 37 Jember, Jawa Timur, Indonesia
}

\begin{abstract}
Integrated Crop Management (ICM) applies various farming technologies through efficient production inputs according to location specifics, so as to produce high productivity to support sustainable production increases. Government programs in increasing production in the form of assistance to farmers are often followed in ICMFS activities and are expected to be included in the program to increase food production programs to achieve the right targets as desired. The result shows that, ICM has been carried out by farmers by choosing rice varieties that are able to adapt to the environment, resistant to pest and disease attacks, have high selling values and have a good taste that is accepted by consumers. The purposes of the farm group is to get capital assistance, increase income and develop farming. The group's objectives are formulated by deliberations with group members, even though group goals do not cover all the needs of group members. Members are given the freedom to convey their ideas and opinions. Group structure is formed based on the agreement of members and deliberations as expected by members. the group structure consists of farmer group leaders, secretaries, treasurers and members. Cooperation among member groups is good and the group leader is able to communicate well. The group's unity is fundamental to the success of the group
\end{abstract}

\section{INTRODUCTION}

Food crops, especially rice, have a dominant role in the economy, both in terms of production and household consumption or expenditure. Rice is a staple food, so rice cannot be separated from the problem of food security that must be solved in a sustainable manner so as not to hamper the development of the agricultural sector. Increasing rice production has always been a government priority.

Implementation of the strategy to increase productivity is realized through Integrated Crop Management (ICM). ICM provides new innovations in solving various problems related to increasing rice productivity and farmers' income so that farmers' welfare can be realized. Rice productivity can be increased through two ways, namely developing and adopting new technologies and the use of available resources more efficiently. The existence of technology is one of the absolute requirements in agricultural development. Technology plays a role in increasing farmers' productivity and income because technology also determines the production process [1].

Integrated Crop Management (ICM) is a new innovation to solve various problems in increasing productivity [2] The technology component of Integrated Crop Management (ICM) is determined together with farmers through technology needs analysis. Indicators of Corresponding author: Lenny.faperta@unej.ac.id the success of the integrated crop management field school (ICMFS) can be seen from the increase in farmers' knowledge, skills and attitude changes, the application of good and right cultivation, increased productivity and sustainability as well as its dissemination. In ICMFS activities, farmers can learn directly in the field through direct learning and appreciation, expressing, analyzing, concluding and applying to solve major problems in rice cultivation techniques [3].

The strategy to increase food crop production can be done by using quality superior seeds, legowo planting systems and the use of organic fertilizers and biobiological fertilizers, irrigation management, and improved cultivation. This strategy is mainly implemented in areas where expansion is difficult, so that the application of site-specific technology is expected to increase productivity. Another thing that can be applied is to reduce the potential loss of yield through better handling of harvest and post-harvest.

The ICMFS program objectives: 1 . Provide farmers with an understanding of Integrated Crop Management; 2. Increasing knowledge, skills and changing attitudes of farmers to accelerate the application of the technology component of rice in their farming so that the dissemination of technology to other farmers runs faster 3 . Increase productivity, production, income and welfare of farmers. [3].

The application of ICM is based on five main principles: ICM is a management approach in integrated 
plant, land and water resources; ICM is site-specific, so application technological components do not apply general; based on a synergistic relationship between two or more production technology; ICM is dynamic so that it continues to grow in accordance with technology progress; ICM is open participatory wide space for farmers to choose, practice, give advice, and convey knowledge it has to other farmers [4]

The ICM program requires the support of farmer group members. The behavior and activities of farmer group members will influence the dynamics within the group and the problems in the field that arise in implementing ICM activities.

Farmer groups as learning classes, is a place for teaching and learning for members to improve knowledge, skills and attitudes as well as the growth and development of independence in farming. Farmer groups as a place to strengthen cooperation between farmers in groups and between farmer groups and members of other groups. Whereas the farmer group as a farm production unit carried out by each member of the farmer group as a whole, must be seen as an effort that can be developed to achieve economies of scale, both in terms of quality and quantity [5]

The more effective the group, the better the lives of the members in the group. A concept that shows the effectiveness of the group in achieving its goals is the concept of group dynamics. A group or organization can be said to be dynamic if the group or organization is effective in achieving its goals [6]

Psycho-social approach in group dynamics is to examine everything that affects the behavior of group members in carrying out activities for the achievement of group goals through elements of group dynamics, namely: 1. A group goal is something that the group wants to achieve; 2. Group structure is a group component that regulates interactions in groups to achieve goals; 3 . Group functions are all things related to efforts to facilitate and coordinate group efforts regarding problems faced by members and efforts to solve those problems; 4. Coaching and group development are all efforts to keep the group active; 5. Group unity and cohesiveness is a strong commitment from all members to achieve the goals, unity, and group unity become the strength for the group to achieve goals and overcome obstacles; 6. Group atmosphere is the mental attitude and feelings that are generally present in groups; 7. Group pressure and tension is a comfortable and uncomfortable atmosphere felt by members in the group; 8. Group effectiveness is basically the ability of groups to achieve goals; 9. Covert intent is a program, task or goal that is not known or realized by group members [7] This aspect of group dynamics provides maximum opportunities for members to collaborate and participate in group activities [8] [9]

The realization of dynamic groups is influenced by external and internal factors. External factors come from outside the group while internal factors come from the members themselves which will lead to interaction among members, exchanging opinions and experiences which will later increase knowledge for others. The purpose of the research was to evaluate the implementation of integrated crop management (ICM) and identified the dynamics of the farmer's group in the Arjasa Village.

\section{RESEARCH METHODOLOGY}

This study used both primary and secondary data. Primary data was collected through deep interviews among informants. Secondary data were gathered from report of the extension workers, Arjasa statistical board, previous researcher and other related studies. The subject of the research is chosen purposively.

The informants are member of group farmer namely Tani Makmur who participated in Integrated Crop Management Field School (ICMFS). The number of informants are 7 farmers. The method of determining key informant using Purposive Sampling. Data from interview were processed and analyzed using Milles and Huberman [10] (Sugiono, 2014). Data analysis is done by showing the interactive nature of data collection or data collection with continuous data analysis. Data collection is placed as a component that is an integral part of data analysis activities [11] (Miles and Huberman, 1984), [10] (Sugiyono (2014), [12] (Bungin, 2012)

\section{RESULTS AND DISCUSSIONS a. Integrated Crop Management (ICM)}

Implementation of integrated crop management is done by checking the activities carried out by farmers based on the ICM handbook guideline. This was done to determine the ability and skills of farmers after participating in the ICMFS program. If the activity has been carried out by farmers in accordance with the established ICM handbook guideline, it can be said that group members adopted ICM and implemented it in their farming activities. But if farmers have not been able to implement ICM activities based on the implementation guidelines, it can be said that ICM activities failed to be adopted by members of the farmer groups.

Almost all ICMFS activities guided by extension agents can be implemented by farmers. Various efforts have been made by farmers to be able to improve their rice yields. One of the methods carried out by farmers is by participating in ICMFS activities. The program has provided changes to farmers, because with this activity farmers understand how to manage and plant rice properly, effectively and efficiently. The ICMFS activities that have been carried out and implemented properly by farmers are the selection of good varieties 
and seeds, seedbed and seedling preparation, land preparation, irrigation, while the components implemented but not in accordance with the ICM handbook are planting, fertilizing, weeding, pest control, and harvesting.

The informants have implemented the selection of varieties according to the instructions from the ICM handbook. Every 1 hectare of land requires around 40-45 $\mathrm{kg}$ of seeds. The selection of rice plant varieties is based on the age of planting, resistance to pests and diseases, and the use of certified seeds. This has been done by farmers and in accordance with the ICM manual handbook.

Farmers use certified seeds to produce maximum yields and good quality and do not interfere with cropping patterns. Seed varieties used are Situbagendit varieties with a planting period of around 105 days. The reason farmers use this variety is because the Situbagendit variety has a shorter planting period compared to other varieties and has a fluffier rice texture.

The farmer prepared the nursery first before planting. The nursery is made in groups, this is done by farmers to get good quality seeds and facilitate farmers in caring for the seeds. Nursery is done in groups with the intention that the nursery is more efficient and easier in controlling pest and disease. Seedbed size of $6 \times 5 \mathrm{~m}$ or according to the needs of farmers. Spreading the seeds is done in the nursery area that has been plowed and muddy so that the seeds that are spread can grow well.

The farmer has carried out land management according to the ICM manual handbook. The farmer has carried out land management according to the ICM handbook instructions. Land plowing is done by using a hand tractor and also the process of waterlogging in the rice fields. Soil cultivation is carried out immediately after the harvesting process, because tillage after harvesting can prevent pests and diseases.

To produce good plants, good land management is needed. Soil processing is done to flatten the soil media and prevent weed growth. Land tillage can be done perfectly (twice) or without tillage according to land conditions [13] (BPTP NAD, 2009)

Irrigation is done twice during the planting period at the age of 0-15 days and 25-40 days. Farmers do not over-irrigate or too much apply on their paddy fields because excessive watering will cause rot on rice plants. The planting process is carried out on muddy soils because it makes it easy for farmers during the planting process.

\section{b. Group dynamics}

Farmer group dynamics is the activities that occur within a farmer group that causes a change in the farmer group. The activities of the group members include group member activities, and initiatives that are used as a measure of the dynamics of the farmer groups.
The determination of the activities of farmer group members uses psycho-social approach. The intended indicators include farmer group goals, task functions, group coaching and development, group unity, group atmosphere, group pressure, group effectiveness, and covert intentions. The researcher considers that the indicators used can be representative for analyzing the activities of farmer group members. Group dynamics greatly determine the participation and effectiveness of group members in adopting the innovations provided by extension worker.

Group dynamics are influenced by group members. The dynamics of group members can provide an overview of group dynamics. The activities of group members consist of activities, creativity, and initiatives that are used as a standart of the dynamics of farmer groups. Group dynamics were analyzed based on: group goals, organizational structure, group task functions, group development, group effectiveness, group solidarity, group atmosphere, and group pressure.

\section{The Goal of Farmer Group}

The aim of farmer groups is to get capital assistance, increase income and be able to develop farming. The results of the study indicate that group goals are determined based on agreement between group members. Farmer group members want to get capital assistance, improve the quality of their farming. In the other hand, being a member of a group causes farmers understand the techniques of integrated rice cultivation. Although some farmers were not satisfied with the program activities because of the limited time in each activity. While group goals have not covered all the needs of group members.

\section{Group Structure}

The group structure has been formed based on the agreement of members consisting of head of farmer groups, secretaries, treasurers, and members. All group members know the group organizational structure. Farmers state that there are plans and work programs in the long term, although there are farmers who are hesitant about the farmer's work program. Long-term plans are carried out to enhance cooperation with the Regional Government and expand marketing. While the short-term work plan is to provide economic services to members, increase the knowledge and skills of members in managing farming and improving the welfare of members

\section{Group Task}

Group task are (1) the task of the group leader is to coordinate, organize, and be responsible for all group activities, (2) the task of the group secretary is to be responsible for implementing each non-financial activity, (3) the task of the group treasurer is to handle all activities financial group. Whereas group members have the rights and obligations such as: the right to share ideas /suggestions / opinions to the board both in meetings and 
outside meetings, to choose and be elected as administrators, and to get the same treatment in accordance with the activities carried out in the group. While the obligations of members are to obey the rules or agreements in the group, obey the decisions of the meeting, attend each member meeting.

\section{Group Development}

Members are always invited by the management to participate in the activities carried out by the group. The invitation of group administrators to members is by reminding them regarding to the group's activities. Group activities supported by community leaders. Group development is carried out by extension agents with regular meetings once $s$ month, during the meeting they are, member of group farmer and extention agent discussing regarding to farming activities, such as: rice cultivation, appliying fertilizer, pesticide, irrigation management and so on.

\section{Group Solidarity}

The farmer groups get along well even though in each group there is an internal conflict. If there is a conflict, then group members look for solutions to solve problems. Conflicts that occur between members in a group as a result of differences of opinion between group members, but this can be resolved by way of deliberation. Regarding to them, sometime they had problem with other, but the problem they faced is not big problem.

\section{Group atmosphere}

The desired atmosphere is freedom of conveying information, sharing idea among members and with extensionist so that it can foster a feeling of enthusiasm and brotherhood. The informant stated that farmer groups are like a second home for them. Farmer groups are built with family relationships, so that each group member feels comfortable being a group member. In addition, being a member of a farmer group makes it easy for them to get solutions to the problems they face, especially in farming. Between members of the group are open to convey important information relating to farm activities. If there is a member of a farmer group having difficulties for example in fertilizing, then another member who understands or has the same experience, then he informs the experience to the other farmer group members.

\section{Group Effectiveness}

The group is effective if it succeeds in achieving its objectives, meaning that changes are both physical and non-physical that can satisfy its members. Group effectiveness has a reciprocal influence with group dynamics. Effective groups have high dynamics, whereas ineffective groups do not have high dynamics in achieving their goals.

Since they joined the farmer group, they feel that being a member of group farmer provides positive benefits for farmers and becomes better in farm management. They feel that information is more easily obtained and problems related to farming more quickly get solutions, in addition they feel that the knowledge they have is also broader. Being a member of a farmer group, allows them to participate in activities carried out by the Department of Agriculture, one of which is ICMFS program. By participating in the ICMFS program, they feel positive benefits, especially in farming management.

\section{CONCLUSION}

Farmers are able to implement integrated crop management components. All integrated plant management activities guided by extension workers can be carried out by farmers. Farmers make various efforts to improve crop yields. One way that is done by farmers is by participating in integrated plant management field school.

The integrated crop management school has provided a change for farmers, because farmers are able to manage rice farming well, effectively and efficiently. The components carried out by farmers are the use of superior seed, seedbed, and seedling preparation, land processing, irrigation management, use of fertilization, weeding, pest control, and harvesting based on ICM manual handbook. The more the dinamic of the group, the easier the integrated crop management to be implemented. If the integrated crop management implemented properly, so it will affect to the productivity and eficient used of input production

\section{REFERENCES}

1. Mira Apriani, Dwi Rachmina, dan Amzul Rifin, The Effect of Implementation of Integrated Crop Management Technology (ICM) Toward Technical Efficiency on Rice Farming. Jurnal Agribisnis Indonesia (Vol 6 No. 2, December 2018); page 121-132 121 ISSN 2354-5690; E-ISSN 2579-3594 (2018).

2. Director General of Food Crops. Technical Guidelines for Integrated Crop Management Field School (ICMFS) in Rice Farming. Jakarta

https://ejournal.unsrat.ac.id/index.php/cocos/ article/view/12504 (2012).

3. Ministry of Agriculture. Technical Guidelines for Integrated Crop Management Field School (ICMFS) in rice and corn farming.

http://pusdatin.setjen.deptan.go.id/ditjentp/fil es/Pednis_SL-PTT 2013.pdf. (2013).

4. Maintang, Integrated Crop Management and Farmer Choice Technology: The Case of South Sulawesi, Iptek Tanaman Pangan Vol. 7 No. 2. 2012 (2012).

5. Lestari, Mugi. Group Dynamics and 
Independence of Group's Member in Farming in Poncowarno District, Kebumen Regency, Central Java Province. Thesis. Surakarta: Post Graduate Program Sebelas Maret University (2011).

6. Charly Kojansow, Jenny Baroleh, Martha M. Sendow . The Dynamics of the Sarongsong Youth Farmer Group in Tumatangtang Satu Village, South Tomohon District, Tomohon City. Agri-Sosio Ekonomi Unsrat, ISSN 1907- 4298, Vol 12 Number 3, September 2016 : 19 - 30 (2016).

7. Huraerah dan Purwanto. 2006. Group Dynamics. PT. Refika Aditama. Bandung (2016).

8. Novtrianto Makawekes, Lyndon R.J. Pangemanan, Melsje Y. Memah. Dynamics of Cempaka Farmers Group In Meras Village Bunaken Sub-district Manado Municipality. Cocos Journal, Vol 7 no 3 (2016).

9. Juwendi Poluan, Ventje V. Rantung, Charles R. Ngangi. The Dynamics of Maesaan Waya
Group Farmer in Manembo Village, South Langowan, Agri-SosioEkonomi Unsrat, ISSN 1907-4298, Vol 13 No. 1 A, Januari 2017 : page 217 - 224 (2017).

10 Sugiyono. Understanding Qualitative Research. Bandung: CV. Alfabeta (2014).

11. Miles, M. B. \& Huberman, A. M. (1984). Qualitative Data Analysis: A Sourcebook of New Methods. California; SAGE publications Inc (1984).

12. Burhan Bungin, Qualitative Data Analysis Philosophical and Methodological Understanding in Application Model. PT Raja Grafindo Persada (2012)

13. Aceh Food Security and Agricultural Extension Agency. Rice Cultivation. Nangro Aceh Darussalam Agricultural Technology Research Center (2009) 